\title{
PENGARUH PELATIHAN, SIKAP, INTENSI, DAN MODAL TERHADAP PERILAKU BERWIRAUSAHA PADA PESERTA PROGRAM MAHASISWA WIRAUSAHA
}

\author{
Ni Made Anintia Trisna Sari \\ Jurusan Pendidikan Ekonomi, Fakultas Ekonomi dan Bisnis \\ Universitas Pendidikan Ganesha \\ Singaraja, Indonesia
}

Email : anintia trisnasari@yahoo.com

\begin{abstract}
Abstrak
Penelitian ini bertujuan untuk mengetahui (1) pengaruh pelatihan pengusaha terhadap perilaku kewirausahaan melalui sikap pengusaha, (2) pengaruh pelatihan pengusaha terhadap perilaku kewirausahaan melalui sikap pengusaha dan niat kewirausahaan, dan (3) modal sebagai variabel moderator yang memperkuat pengaruh pelatihan wirausaha, sikap pengusaha, dan kewirausahaan niat terhadap perilaku kewirausahaan. Jenis subjek ini adalah ex-post facto penelitian. Penentuan sampel penelitian ini dihitung dengan menggunakan teknik Slovin. Berdasarkan hasil perhitungan yang didapatkan 41 orang sebagai sampel. Pengumpulan data dilakukan dengan menggunakan metode dokumentasi dan kuesioner. Kemudian, data dianalisis dengan analisis jalur dan analisis regresi moderat. Hasil penelitian ini menunjukkan bahwa (1) pelatihan pengusaha memberikan pengaruh positif dan signifikan terhadap perilaku kewirausahaan melalui sikap pengusaha, (2) pelatihan pengusaha memberikan pengaruh positif dan signifikan terhadap perilaku kewirausahaan melalui sikap pengusaha dan niat kewirausahaan, dan (3) modal tidak variabel moderator yang memperkuat pengaruh pelatihan wirausaha, sikap pengusaha, dan niat kewirausahaan terhadap perilaku kewirausahaan
\end{abstract}

Kata Kunci: modal, niat kewirausahaan, pelatihan wirausaha, perilaku kewirausahaan, sikap pengusaha

\begin{abstract}
This study aimed at knowing (1) the influence of entrepreneur training toward entrepreneurship behavior through entrepreneur attitude, (2) the influence of entrepreneur training toward entrepreneurship behavior through entrepreneur attitude and entrepreneurship intention, and (3) capital as moderator variable that strengthen the influence of entrepreneur training, entrepreneur attitude, and entrepreneurship intention toward entrepreneurship behavior. The type of this subject is ex-post facto research. Sample determination of this study is counted by using Slovin technique. Based on the calculation result of it, 41 people as sample is got. Data collection is done by using documentation and questioner methods. Then, the data is analyzed by path analysis and moderate regression analysis. The result of this study shows that (1) entrepreneur training gives positive and significant influence toward entrepreneurship behaviorthrough entrepreneur attitude, (2) entrepreneur training gives positive and significant influence toward entrepreneurship behavior through entrepreneur attitude and entrepreneurship intention, and (3) capital is not a moderator
\end{abstract}


variable which strengthen the influence of entrepreneur training, entrepreneur attitude, and entrepreneurship intention toward entrepreneurship behavior.

Keywords: Capital, entrepreneur attitude, entrepreneurship behavior, entrepreneurship intention, entrepreneur training

\section{PENDAHULUAN}

Kewirausahaan adalah pilar utama meningkatkan kualitas kegiatan ekonomi. Pembangunan bangsa dapat dilakukan dengan kewirausahaan karena kewirausahaan merupakan salah satu inovasi yang dapat meningkatkan pembangunan ekonomi (Rajasa, 2013). Namun kewirausahaan tidak serta merta berkembang begitu saja, sehingga diperlukan usaha yang sungguh-sungguh agar dapat menumbuhkan kewirausahaan tersebut. Kewirausahaan yang dijalankan akan mencapai keberhasilannya apabila seorang wirausahawan tersebut memiliki sikap kewirausahaan. Jika seseorang wirausahawan setengah-setengah (tidak memiliki sikap kewirausahaan) dalam menjalankan usaha akan mengakibatkan usaha tersebut menjadi labil dan gagal (Zimmerer dan Scarborough, 2005).

Sikap kewirausahaan adalah kesiapan seseorang untuk merespon secara konsisten terhadap ciri-ciri yang dimiliki oleh seorang wirausaha, yaitu percaya diri, berorientasi pada tugas dan hasil, pengambilan risiko dan suka tantangan, kepemimpinan, keorisinilan, dan berorientasi ke masa depan (Meredith, 2005). Faktor sikap kewirausahaan juga dipercayai akan membentuk intensi/niat berwirausaha dan perilaku (Gurbuz dan Aykol, 2008; Green, 1972).

Theory of Planned $\begin{gathered}\text { Behavior } \\ \text { menyatakan }\end{gathered}$
bahwa

merupakan variabel antara yang menyebabkan terjadinya perilaku dari suatu sikap maupun variabel lainnya (Ajzen, 1988). Intensi/niat berwirausaha ini dapat diukur dengan indikator memilih jalur usaha daripada bekerja pada orang lain, memilih karir sebagai wirausahawan, dan perencanaan untuk memulai usaha (Ramayah dan Harun, 2005). Penelitian sebelumnya telah membukti bahwa faktor sikap berpengaruh secara positif dan signifikan terhadap intensi berwirausaha (Suharti dan Hani, 2011; Soewarno; Krueger et. al, 2000; Kourilsky dan Walstad, 1998).

Dalam Theory Planned Behavior juga menjelaskan bahwa intensi/niat dapat mempengaruhi perilaku seseorang (Ajzen, 1988). Perilaku yang dilakukan oleh seseorang disebut sebagai perilaku yang tampak (overt behaviour). Unsurunsur perilaku yang tampak berupa tingkah laku (Walgito, 2003). Penelitian Krueger et. al (2000) serta Kourilsky dan Walstad (1998) membuktikan bahwa sikap secara tidak langsung dapat mempengaruhi perilaku seseorang melalui intensi. Jadi intensi merupakan prediktor dari setiap perilaku seseorang. Namun, menurut Green (1972) faktor yang mempengaruhi perilaku adalah sikap sebagai faktor predisposisi. Sikap yang ada pada seseorang akan menampilkan suatu perilaku nyata sebagai seorang wirausaha. Penelitian Mulyadi (2010) telah membuktikan bahwa sikap berpengaruh terhadap perilaku. 


\begin{abstract}
Perguruan tinggi sebagai salah satu lembaga pendidikan seharusnya mengubah pola pikir mahasiswa yang bukan hanya sebagai pencari kerja, tetapi juga sebagai pencipta lapangan kerja. Oleh sebab itu, perlu ditanamkan jiwa kewirausahaan kepada mahasiswa dengan memberikan pengetahuan kewirausahaan, baik dengan cara memasukkan pendidikan kewirausahaan ke dalam kurikulum inti maupun dengan cara memberikan pelatihan-pelatihan kewirausahaan. Pihak perguruan tinggi perlu menerapkan pola pembelajaran kewirausahaan yang kongkrit untuk membekali mahasiswa dengan pengetahuan yang bermakna agar dapat mendorong semangat mahasiswa untuk berwirausaha (Yohnson 2003, Wu dan $\mathrm{Wu}, 2008)$
\end{abstract}

Pelatihan sangat berperan untuk mengembangkan keahlian, keterampilan, pengetahuan, sikap, dan perilaku guna memenuhi tuntutan pekerjaan yang terus berubah (Brockhaus dalam Bell, 2008; Noe et.al., 2003; Bernardi dan Russel, 1998; Moekijat, 1993), sehingga diharapkan dapat membiasakan cara berpikir dan bersikap mental maju sehingga peserta pelatihan memiliki jiwa wirausaha (Riyanto, 2000). Penelitian sebelumnya, membuktikan bahwa pelatihan memberikan pengaruh terhadap pembentukan sikap dan perilaku (Pertiwi dkk, 2012; Mustikawati dkk, 2010, Mulyadi, 2010; Bangun, 2007; Kourilsky dan Walstad, 1998; Sarwoko, 2011).

Pelatihan, sikap, intensi, dan perilaku berwirausaha memang dibutuhkan dalam menjalankan usaha, akan tetapi keempat hal tersebut tidak akan berguna apabila tidak ada dukungan modal. Modal merupakan salah satu faktor produksi yang penting dalam menjalankan sebuah usaha baik berupa uang maupun barang. Modal bersama faktor produksi lain (sumber daya dan tenaga kerja) dikelola untuk menghasilkan barang-barang baru (Griffin, 2006; Marbun, 2003; Gilarso, 1993; Magdalena dan Soewartoyo, 1992). Hal tersebut didukung oleh Theory Entrepreneurial Event menjelaskan bahwa ketersedian modal merupakan salah satu kondisi yang mendukung seseorang menjadi wirausaha (Shapero dan Sokol, 1982).

Penelitian ini bertujuan, yaitu untuk mengetahui pengaruh pelatihan kewirausahaan terhadap perilaku berwirausaha melalui sikap kewirausahaan, untuk mengetahui pengaruh pelatihan kewirausahaan terhadap perilaku berwirausaha melalui sikap kewirausahaan dan intensi berwirausaha, dan untuk mengetahui modal sebagai variabel moderator yang memperkuat pengaruh pelatihan kewirausahaan, sikap kewirausahaan, dan intensi berwirausaha terhadap perilaku berwirausaha.

\section{METODE}

Jenis penelitian ini adalah penelitian ex post facto yang bertujuan menemukan penyebab yang memungkinkan perubahan perilaku, gejala atau fenomena yang dari suatu peristiwa dan penyebab perubahan pada variabel bebas yang secara keseluruhan sudah terjadi. Variabel yang digunakan dalam penelitian ini ada lima, yaitu pelatihan kewirausahaan $\left(X_{1}\right)$, sikap kewirausahaan $\left(X_{2}\right)$, intensi berwirausaha $\left(X_{3}\right)$, modal $\left(X_{4}\right)$ dan perilaku berwirausaha $(Y)$. Hasil dari penelitian ini diharapkan dapat menjelaskan mengenai pengaruh $X_{1}, X_{2}$, $X_{3}$, dan $X_{4}$ terhadap $Y$. Subjek dalam 
penelitian ini adalah peserta Program Mahasiswa Wirausaha Universitas Pendidikan Ganesha tahun 2012. Analisis yang digunakan dalam penelitian ini adalah analisis jalur dan analisis regresi moderat dengan bantuan SPSS for Windows versi16.0. Pengumpulan data dilakukan dengan metode dokumentasi dan kuesioner.

Tabel 1. Hasil Analisis Pengaruh Pelatihan Kewirausahaan terhadap Perilaku Berwirausaha melalui Sikap Kewirausahaan

\begin{tabular}{ccccc}
\hline \multicolumn{2}{c}{ Variabel } & Standarized & \multirow{2}{*}{ Sig } & Keterangan \\
\hline Bebas & Terikat & Beta & & \\
\cline { 1 - 3 } $\begin{array}{c}\text { Pelatihan } \\
\text { Kewirausahaan }\end{array}$ & $\begin{array}{c}\text { Sikap } \\
\text { Kewirausahaan }\end{array}$ & 0,691 & 0,000 & Signifikan \\
\hline $\begin{array}{c}\text { Sikap } \\
\text { Kewirausahaan }\end{array}$ & $\begin{array}{c}\text { Perilaku } \\
\text { berwirausaha }\end{array}$ & 0,370 & 0,000 & Signifikan \\
\cline { 1 - 2 }
\end{tabular}

Sumber: Data diolah Peneliti, 2013

HASIL DAN PEMBAHASAN

Pengaruh Pelatihan Kewirausahaan secara Tidak Langsung terhadap Perilaku Berwirausaha melalui Sikap Kewirausahaan

Hipotesis yang diuji dalam bahasan penelitian ini adalah ada pengaruh pelatihan kewirausahaan terhadap perilaku berwirausaha secara tidak langsung melalui sikap kewirausahaan pada peserta Program Mahasiswa Wirausaha Undiksha tahun 2012.Tabel 1 menunjukkan hasil analisis tentang pengaruh pelatihan kewirausahaan secara tidak langsung terhadap perilaku berwirausaha melalui sikap kewirausahaan.
Berdasarkan Tabel 1 dapat dilihat besarnya koefisien dari pengaruh langsung antara pelatihan kewirausahaan terhadap sikap kewirausahaan dalam kolom Beta yaitu 0,691 dengan taraf signifikansi 0,000.Pada tabel tersebut juga dapat dilihat besarnya koefisien dari pengaruh langsung antara sikap kewirausahaan terhadap perilaku berwirausaha dalam kolom Beta yaitu 0,370 dengan taraf signifikasi 0,000.Diagram jalur untuk model pengaruh pelatihan kewirausahaan $\left(X_{1}\right)$ terhadap perilaku berwirausaha $(\mathrm{Y})$ melalui sikap kewirausahaan $\left(\mathrm{X}_{2}\right)$ dapat dilihat pada Gambar 1

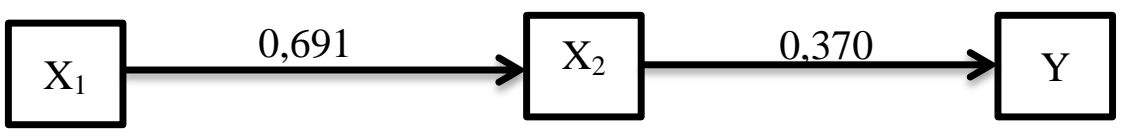

Gambar 1. Blok Jalur Pengaruh $X_{1}$ terhadap $Y$ melalui $X_{2}$

Dari hasil analisis pengaruh pelatihan kewirausahaan terhadap sikap kewirausahaan dan sikap kewirausahaan terhadap perilaku berwirausaha, maka dapat diketahui bahwa Ho ditolak.Jadi, ada pengaruh pelatihan kewirausahaan terhadap perilaku berwirausaha secara tidak langsung melalui sikap 
kewirausahaan pada peserta Program Mahasiswa Wirausaha Undiksha tahun 2012 secara positif dan signifikan.Besarnya kefisien pengaruh secara tidak langsung pelatihan kewirausahaan terhadap perilaku berwirausaha melalui sikap kewirausahaan yaitu $0,619 \times 0,370=$ 0,229 .Jadi, persamaan dari model ini adalah sebagai berikut.
BLOK 1

$$
\begin{gathered}
X_{2}=\rho 21 \mathrm{X} 1+\rho \mathrm{X} 2 \varepsilon 1 \\
P_{x 2 e 1}=\sqrt{1-R_{1}^{2}} \\
=\sqrt{1-0,478^{2}}=0,878 \\
X_{2}=0,691 \mathrm{X} 1+0,878 \varepsilon 1
\end{gathered}
$$

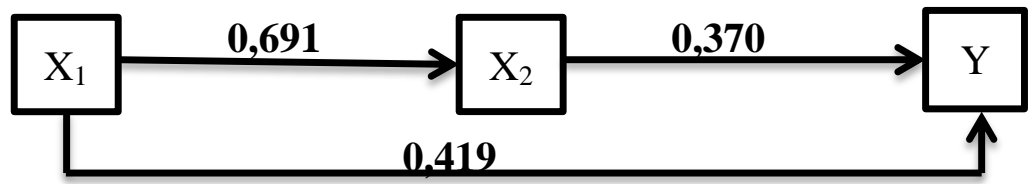

Gambar 4.6 Model Diagram Jalur Variabel $\mathrm{X}_{1}$ terhadap $\mathrm{Y}$ melalui $\mathrm{X}_{2}$

Tabel 2. Ringkasan Hubungan Antar Variabel $X_{1}$ terhadap $Y$ melalui $X_{2}$

\begin{tabular}{llllll}
\hline No. Hubungan & $\begin{array}{l}\text { Pengaruh } \\
\text { Langsung }\end{array}$ & $\begin{array}{l}\text { Pengaruh } \\
\text { Tidak } \\
\text { Langsung } \\
\text { Melalui } \mathrm{X}_{2}\end{array}$ & Pengaruh Total & Sig $t$ \\
\hline 1 & $\mathrm{X}_{1} \rightarrow \mathrm{X}_{2}$ & 0,691 & & 0,691 & 0,000 \\
\hline 2 & $\mathrm{X}_{2} \rightarrow \mathrm{Y}$ & 0,370 & & 0,370 & 0,000 \\
\hline 3 & $\mathrm{X}_{1} \rightarrow \mathrm{Y}$ & 0,419 & $\begin{array}{l}0,691 \mathrm{X} \\
0,370=\end{array}$ & $\begin{array}{l}0,419+0,229= \\
0,229\end{array}$ & 0,648 \\
\hline 4 & $\varepsilon_{1}$ & 0,878 & & 0,878 & 0,000 \\
\hline
\end{tabular}

Sumber: Data diolah Peneliti, 2013

Berdasarkan hasil pengujian hipotesis yang sudah diuraikan di atas, terbukti bahwa pelatihan kewirausahaan berdampak positif pada perilaku berwirausaha melalui sikap kewirausahaan.Jadi, semakin efektif pelaksanaan pelatihannya maka sikap kewirausahaannya semakin tinggi sehingga semakin tinggi pula perilaku berwirausahanya.
Hasil tersebut membuktikan relevansi dari pernyataan Green (1972) juga bahwa terdapat faktor predisposisi (faktor yang mempermudah) terjadinya perilaku, seperti pengetahuan, sikap, keyakinan, kepercayaan, nilai-nilai, dan tradisi.Jadi, seseorang yang menerima atau mengadopsi perilaku baru dengan melalui tiga tahap, yaitu pengetahuan, sikap, praktek atau tindakan. Jadi, seseorang dalam berperilaku tidak begitu 
saja menentukan sikap, akan tetapi mereka menentukan sikap dari pengetahuan yang mereka miliki. Pengetahuan yang dimiliki dapat diperoleh dari pendidikan formal maupun pendidikan nonformal. Salah satu pendidikan nonformal adalah pelatihan.Hal ini juga sejalan dengan hasil penelitian dari Mulyadi (2010), bahwa pendidikan/pelatihan kewirausahaan secara tidak langsung mempengaruhi perilaku berwirausaha melalui sikap kewirausahaan.

\section{Pengaruh Pelatihan Kewirausahaan secara Tidak Langsung terhadap}

\section{Perilaku Berwirausaha melalui Sikap} Kewirausahaan dan Intensi Berwirausaha

Hipotesis dalam bahasan penelitian ini adalah ada pengaruh tidak langsung pelatihan kewirausahaan terhadap perilaku berwirausaha melalui sikap kewirausahaan dan intensi berwirausaha pada peserta Program Mahasiswa Wirausaha Undiksha tahun 2012. Tabel 3 menunjukkan hasil analisis tentang pengaruh pelatihan kewirausahaan secara tidak langsung terhadap perilaku berwirausaha melalui sikap kewirausahaan dan intensi berwirausaha.

Tabel 3. Hasil Analisis Pengaruh Pelatihan Kewirausahaan terhadap Perilaku Berwirausaha melalui Sikap Kewirausahaan danIntensi Berwirausaha

\begin{tabular}{|c|c|c|c|c|}
\hline \multicolumn{2}{|c|}{ Variabel } & \multirow{2}{*}{$\frac{\text { Standarized }}{\text { Beta }}$} & \multirow[b]{2}{*}{ Sig } & \multirow{2}{*}{ Keterangan } \\
\hline Bebas & Terikat & & & \\
\hline $\begin{array}{l}\text { Pelatihan } \\
\text { Kewirausahaan }\end{array}$ & $\begin{array}{l}\text { Sikap } \\
\text { Kewirausahaan }\end{array}$ & 0,691 & 0,000 & Signifikan \\
\hline $\begin{array}{l}\text { Sikap } \\
\text { Kewirausahaan }\end{array}$ & $\begin{array}{l}\text { Intensi } \\
\text { Berwirausaha }\end{array}$ & 0,521 & 0,000 & Signifikan \\
\hline $\begin{array}{l}\text { Intensi } \\
\text { Berwirausaha }\end{array}$ & $\begin{array}{l}\text { Perilaku } \\
\text { berwirausaha }\end{array}$ & 0,300 & 0,000 & Signifikan \\
\hline
\end{tabular}

Sumber: Data diolah Peneliti, 2013

Berdasarkan Tabel 3.dapat dilihat besarnya koefisien dari pengaruh langsung antara pelatihan kewirausahaan terhadap sikap kewirausahaan dalam kolom Beta yaitu 0,691 dengan taraf signifikansi 0,000 . Pada tabel tersebut juga dapat dilihat besarnya koefisien dari pengaruh langsung antara sikap kewirausahaan terhadap intensi berwirausaha dalam kolom Beta yaitu 0,521 dengan taraf signifikasi 0,000 . Kemudian, dalam tabel tersebut juga dapat dilihat besarnya koefisien dari pengaruh langsung antara intensi berwirausaha terhadap perilaku berwirausaha dalam kolom Beta yaitu 0,300 dengan taraf signifikasi 0,000 . Diagram jalur untuk model pengaruh pelatihan kewirausahaan $\left(X_{1}\right)$ terhadap perilaku berwirausaha $(Y)$ melalui sikap kewirausahaan $\left(X_{2}\right)$ dan intensi berwirausaha $\left(X_{3}\right)$ dapat dilihat pada Gambar 3. 


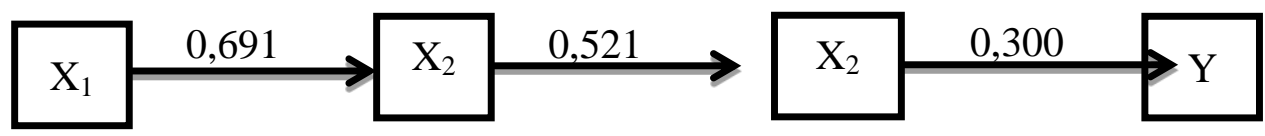

Gambar 3. Blok Jalur Pengaruh $X_{1}$ terhadap $Y$ melalui $X_{2}$ dan $X_{3}$

Dari hasil analisis pengaruh pelatihan kewirausahaan terhadap sikap kewirausahaan, sikap kewirausahaan terhadap intensi berwirausaha, dan intensi berwirausaha terhadap perilaku berwirausaha, maka dapat diketahui bahwa Ho ditolak. Jadi, ada pengaruh pelatihan kewirausahaan terhadap perilaku berwirausaha secara tidak langsung melalui sikap kewirausahaan dan intensi berwirausaha pada peserta Program Mahasiswa Wirausaha Undiksha tahun 2012 secara positif dan signifikan. Besarnya koefisien pengaruh secara tidak langsung pelatihan kewirausahaan terhadap perilaku berwirausaha melalui sikap kewirausahaan dan intensi berwirausaha yaitu $0,619 \times(0,521 \times$
$0,300)=0,108$. Persamaan dari model ini adalah sebagai berikut.

\section{BLOK 2}

$$
\begin{gathered}
\mathrm{X}_{3}=\rho 32 \mathrm{X} 2+\rho \mathrm{X} 3 \varepsilon 2 \\
P_{x 3 e 2}=\sqrt{1-R_{2}^{2}} \\
=\sqrt{1-0,272^{2}}=0,962 \\
X_{3}=0,521 \mathrm{X} 2+0,962 \varepsilon 2
\end{gathered}
$$

\section{BLOK 3}

$$
\begin{gathered}
\mathrm{Y}=\rho \mathrm{Y} 1 \mathrm{X} 1+\rho \mathrm{Y} 2 \mathrm{X} 2+\rho \mathrm{Y} 3 \mathrm{X} 3+\rho \mathrm{Y} \varepsilon 3 \\
P_{Y e 3}=\sqrt{1-R_{3}^{2}} \\
=\sqrt{1-0,889^{2}}=0,458 \\
\mathrm{Y}=0,491 \mathrm{X} 1+0,370 \mathrm{X} 2+0,300 \mathrm{X} 3+ \\
0,458 \varepsilon 3
\end{gathered}
$$

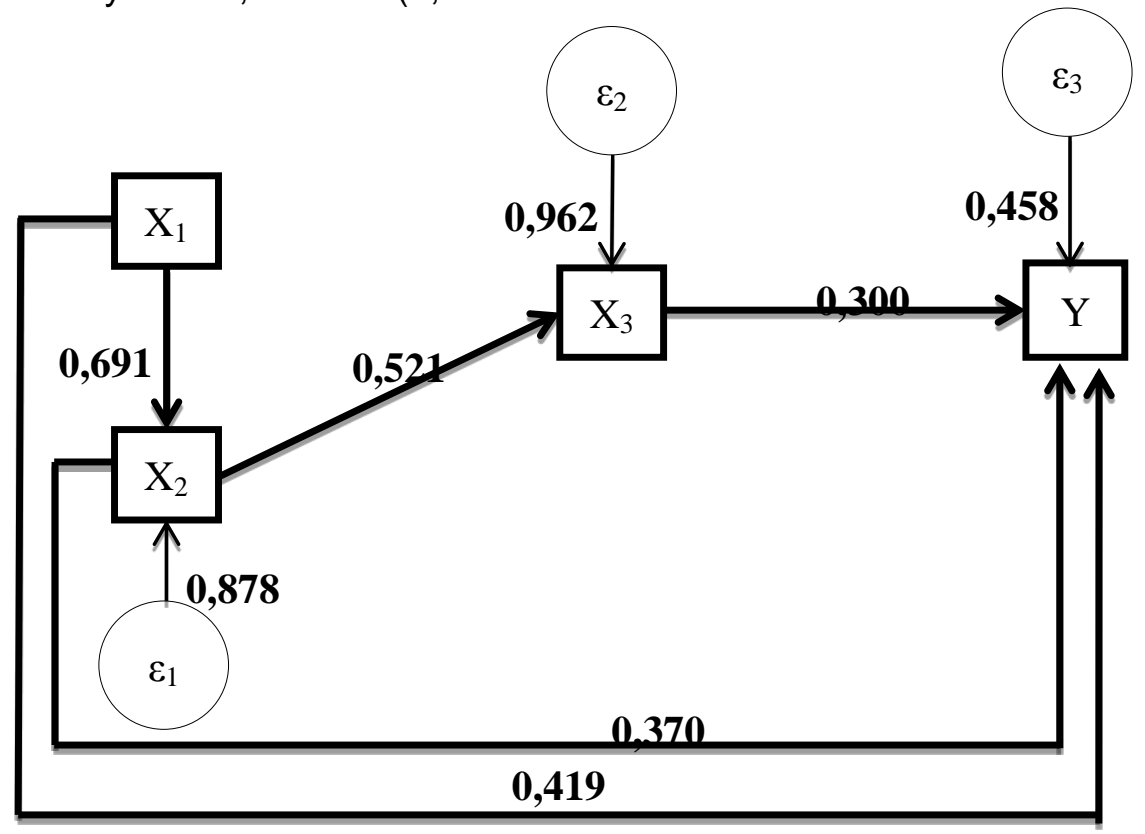

Gambar 4.8. Model Diagram Jalur Variabel $\mathrm{X}_{1}$ terhadap $\mathrm{Y}$ melalui $\mathrm{X}_{2}$ dan $\mathrm{X}_{3}$ 
Tabel 4. Ringkasan Hubungan Antar Variabel $X_{1}$ terhadap $Y$ melalui $X_{2}$ dan $X_{3}$

\begin{tabular}{|c|c|c|c|c|c|}
\hline No. & Hubungan & $\begin{array}{l}\text { Pengaruh } \\
\text { Langsung }\end{array}$ & $\begin{array}{l}\text { Pengaruh Tidak Langsung } \\
\text { Melalui } X_{2} \text { dan } X_{3}\end{array}$ & Pengaruh Total & Sig $t$ \\
\hline 1 & $\mathrm{X}_{1} \rightarrow \mathrm{X}_{2}$ & 0,691 & & 0,691 & 0,000 \\
\hline & $\mathrm{X}_{2} \rightarrow \mathrm{X}_{3}$ & 0,521 & & 0,521 & \\
\hline 2 & $\mathrm{X}_{3} \rightarrow \mathrm{Y}$ & 0,300 & & 0,300 & 0,000 \\
\hline 3 & $\mathrm{X}_{1} \rightarrow \mathrm{Y}$ & 0,419 & $\begin{array}{l}0,691 \times 0,521 \times 0,300= \\
0,108\end{array}$ & $\begin{array}{l}0,419+0,108 \\
0.527\end{array}$ & $=0,000$ \\
\hline 4 & $\varepsilon_{2}$ & 0,962 & & 0,962 & \\
\hline 5 & $\varepsilon_{3}$ & 0,458 & & 0,458 & \\
\hline
\end{tabular}

Sumber: data penelitian diolah

Berdasarkan hasil pengujian hipotesis di atas, terbukti pelatihan kewirausahaan berdampak positif pada perilaku berwirausaha melalui sikap kewirausahaan dan intensi berwirausaha. Hasil tersebut membuktikan relevansi dari Theory of Planned Behavior, perilaku seseorang terbentuk dari intensi (intention) yang merupakan variabel antara yang menyebabkan terjadinya perilaku dari suatu sikap maupun variabel lainnya (Ajzen, 1991). Intensi seseorang terhadap perilaku dibentuk oleh faktor utama yaitu sikap perilaku tertentu (attitude toward the behavior), norma subjektif (subjective norms) dan kontrol perilaku (perceived behavioral control). Hal ini juga mempertegas penyataan Green (1972) bahwa terdapat faktor predisposisi (faktor yang mempermudah) terjadinya perilaku, seperti pengetahuan, sikap, keyakinan, kepercayaan, nilai-nilai, dan tradisi.

Penelitian Kourilsky dan Walstad (1998) menjelaskan bahwa seseorang dalam berperilaku tidak begitu saja menentukan sikap dan memiliki intensi/niat, akan tetapi mereka menentukan sikap dari pengetahuan yang mereka miliki. Penelitian tersebut menguji Theory of Planned Behavior yang memperoleh hasil bahwa pendidikan kewirausahaan secara langsung maupun tidak langsung dapat mepengaruhi perilaku berwirausaha melalui sikap dan intensi.

\section{Modal sebagai Variabel Moderator yang Memperkuat Pengaruh Pelatihan Kewirausahaan, Sikap Kewirausahaan, dan Intensi Berwirausaha terhadap Perilaku Berwirausaha}

Hipotesis dalam bahasan penelitian ini adalah modal memperkuat pengaruh pelatihan kewirausahaan, sikap kewirausahaan, dan intensi berwirausaha terhadap perilaku berwirausaha pada peserta Program Mahasiswa Wirausaha Undiksha tahun 2012.Untuk membuktikan hipotesis ini digunakan analisis regresi moderat yaitu uji residual.Uji residual dilakukan untuk menghindari terjadinya multikolinieritas yang tinggi diantara variabel.Dalam uji residual dilakukan beberapa langkah-langkah. Pertama, meregres variabel pelatihan kewirausahaan $\left(X_{1}\right)$, sikap kewirausahaan $\left(X_{2}\right)$ dan intensi berwirausaha $\left(X_{3}\right)$, terhadap modal $\left(\mathrm{X}_{4}\right)$. Kedua, membuat nilai residual tersebut menjadi nilai absolut yang diberi nama AbsRes_1. Ketiga, meregres variabel AbsRes_1 terhadap perilaku berwirausaha $(Y)$ yang 
kemudian disebut sebagai analisis regresi

moderat.

Tabel 5. Hasil Analisis Modal sebagai Variabel Moderator

Coefficients $^{\mathrm{a}}$

\begin{tabular}{|c|c|c|c|c|c|}
\hline \multirow[b]{2}{*}{ Model } & \multicolumn{2}{|c|}{ Unstandardized Coefficients } & \multirow{2}{*}{$\frac{\text { Standardized Coefficients }}{\text { Beta }}$} & \multirow[b]{2}{*}{ t } & \multirow[b]{2}{*}{ Sig. } \\
\hline & B & Std. Error & & & \\
\hline 1 (Constant) & -1.955 & 2.897 & & -.675 & \\
\hline Perilaku berwirausaha & 151 & .089 & .26 & 1.687 & \\
\hline
\end{tabular}

a. Dependent Variable: AbsRes_1

Sumber: data penelitian diolah

Hasil analisis regresi moderat dalam penelitian ini ditunjukkan pada Tabel 5. Berdasarkan tabel tersebut dapat diketahui bahwa modal bukan sebagai variabel moderator yang memperkuat pengaruh pelatihan kewirausahaan, sikap kewirausahaa, dan intensi kewirausahaan terhadap perilaku berwirausaha.Hasil analisis tidak memperoleh hasil yang signifikan dan koefisien regresinya tidak negatif. Jadi hipotesis yang dibahas dalam penelitian ini membuktikan bahwa Ho diterima, maka modal bukan sebagai variabel moderator yang memperkuat pengaruh pelatihan kewirausahaan, sikap kewirausahaan, dan intensi berwirausaha terhadap perilaku berwirausaha pada peserta Program Mahasiswa Wirausaha Undiksha tahun 2012.

Dikatakan bukan sebagai variabel moderator karena hasil analisis tidak memperoleh hasil yang signifikan dan koefisien regresinya tidak negatif.Padahal, dalam analisis residual ingin menguji pengaruh deviasi (penyimpangan) dari suatu model. Fokusnya adalah ketidakcocokan (lack of fit) yang dihasilkan dari deviasi hubungan linear antar variabel independen dan moderat. Lack of fit ditunjukkan oleh nilai residual didalam regresi. Dalam penelitian ini, dikatakan terjadi ketidakcocokan apabila variabel pelatihan kewirausahaan $\left(X_{1}\right)$, sikap kewirausahaan $\left(X_{2}\right)$, dan intensi berwirausaha $\left(X_{3}\right)$ tinggi, tetapi variabel modal $\left(X_{4}\right)$ rendah sehingga variabel perilaku $\left(X_{5}\right)$ menjadi rendah. Namun, hasil dari penelitian ini tidak menunjukkan lack of fit tersebut dan hasil yang diperoleh juga tidak signifikan.

Hasil penelitian ini tidak sesuai dengan Theory Entrepreneurial Event, yang menyatakan bahwa ketersediaan modal menjadi salah satu pemicu terjadinya perilaku berwirausaha (Shapero dan Sokol 1982). Tidak terbuktinya modal sebagai variabel moderator dalam penelitian ini dapat terjadi karena modal bukan satu-satunya faktor yang memperkuat terjadinya perilaku. Masih ada faktor-faktor lain yang memperkuat terjadinya perilaku dari persepsi individual. Dasar dari persepsi dalam memandang kewirausahaan tidak hanya dari modal.Modal hanya salah satu dari persepsi positif dalam perception of feasibility.

Dalam Theory Entrepreneurial Event (Shapero dan Sokol 1982), persepsi lain dalam memandang kewirausahaan ada dua, yaitu 
perceptions of desirability dan perception of feasibility. Perceptions of desirability, mengacu pada ketertarikan seseorang terhadap suatu perilaku untuk menjadi seorang wirausaha.Perception of feasibility, mengacu pada perasaan seseorang yang menganggap dirinya secara personal mampu melakukan suatu perilaku. Tingkat ketertarikan individu terhadap kewirausahaan dipengaruhi oleh faktor-faktor yang dialami, misalnya negative displacement (seperti terkena PHK, tertekan, terhina, atau bosan dengan pekerjaan yang lama) dan being between things (baru keluar dari penjara atau baru lulus sekolah). Selain itu, keyakinan diri individu untuk menjadi wirausahawan sangat dipengaruhi oleh having positive pull, yaitu suatu kondisi dengan dukungan dari lingkungannya untuk menjadi wirausahawan misalnya ketersediaan modal yang cukup, pasar potensial, dan mentor yang siap membimbing.

\section{SIMPULAN DAN SARAN}

Berdasarkan hasil penelitian dan pembahasan yang telah diuraikan dapat disimpulkan bahwa penelitian ini membuktikan bahwa apa yang diindikasikan oleh pernyataan Moekijat (1993), Green (1982) dan Theory Planned Behavior yang memprediksi bahwa pelatihan, sikap, dan intensi diduga berpengaruh terhadap prestasi akademik melalui minat menjadi guru sepenuhnya berlaku di lingkungan peserta Program Mahasiswa Wirausaha Universitas Pendidikan Ganesha tahun 2012. Namun, Theory Entreprenurial Event yang menduga bahwa modal memperkuat pengaruh pelatihan kewirausahaan, sikap kewirausahaan, dan intensi berwirausaha terhadap perilaku berwirausaha tidak berlaku di lingkungan peserta Program Mahasiswa Wirausaha Universitas Pendidikan Ganesha tahun 2012.Tidak adanya pengaruh modal terhadap hubungan yang memperkuat antara pelatihan, sikap, dan intensi dengan perilaku berwirausaha disebabkan karena pengukuran besarnya modal usaha itu sendiri. Besarnya modal yang diberikan dalam kegiatan PMW ini rata-rata sama.

Berdasarkan kesimpulan di atas, maka dapat disarankan dalam pelaksanaan pelatihan PMW di Univesitas Pendidikan Ganesha agar lebih ditingkatkan dan lebih memperhatikan komponen-komponen dalam pelatihan terutama komponen fasilitas pelatihan. Selain itu, komponen lain juga perlu diperhatikan, seperti (a) tujuan sasaran pelatihan diuraikan ke dalam perilaku-perilaku agar dapat diamati dan diukur sehingga diketahui efektivitas dari pelatihan itu sendiri; (b) pelatih yang harus dapat mengajarkan bahan-bahan pelatihan dengan metode tertentu seperti studi kasus dan diskusi kelompok, brainstorming, ceramah, demonstrasi, simulasi, maupun presentasi sehingga dengan penggunaan metode yang tepat diharapkan peserta memperoleh pengetahuan, ketrampilan, dan sikap yang diperlukan sesuai dengan sasaran yang ditetapkan, (c) materi yang telah disusun berdasarkan sasaran pelatihan yang telah ditetapkan, (d) metode latihan (termasuk alat bantu) yang tepat, dan (e) peserta harus memiliki minat dan 
motivasi dalam berwirausaha agar mengikuti kegiatan PMW serta menjalankan usaha yang dirancang dengan sungguh-sungguh. Sebaiknya peserta yang mengikuti kegiatan PMW memiliki minat untuk berwirausaha sehingga peserta dapat mengikuti kegiatan dengan sungguhsungguh agar tujuan dari pelaksanaan PMW dapat tercapai. Tujuan dari PMW tersebut adalah menumbuhkembangkan wirausahawirausaha baru yang berpendi-dikan tinggi dan memiliki pola pikir pencipta lapangan pekerjaan. Modal yang diberikan sebaiknya disesuaikan dengan usaha yang akan didirikan. Jumlah modal yang diperlukan dalam mendirikan usaha dapat dianalisis dari proposal yang dirancang oleh peserta PMW. Dengan demikian, modal yang diberikan dapat bermanfaat untuk kelancaran usaha.

\section{DAFTAR RUJUKAN}

Ajzen, Icek. 1988. Attitude, Personality and Behavior. Open University Press: Milton Keynes.

Bangun, Armansyah Surya. 2007. Pengaruh Pelatihan terhadap Pengetahuan dan Sikap Petugas Kesehatan Puskesmas Dalam Pemanfaatan Paracheck PF di Kabupaten Sleman.Electronic Theses dan Dissertations (ETD), (online), Unversitas Gajah Mada, (http://etd.ugm.ac.id/index.php?mo $d=$ penelitian_detaildansub=Peneliti anDetaildanact $=$ viewdantyp $=$ htmld anbuku_id=35907danobyek_id=4), diakses 3 November 2012.
Bell, Joseph R. Utilization of Problem Based-Learning in an Entrepreneurship Business Planning Course, New England Journal of Entrepreneurship, Spring 2008, pp 53

Bernardin And Russell. 1998. Human Resource Management, Second Edition. Singapore: McGraw-Hill Book Co

Gilarso, T. 1993. Pengantar IImu Ekonomi Bagian Mikro Jilid 2. Jakarta: Penerbit Kanisius.

Green, B.F. $1972 . \quad$ "Attitude Measurement".in G. Lindzey (ed), Handbook of Social Psychology. 1. 335-369. Reading, MA:AddisionWesley.

Griffin, R. 2006. Business. New Jersey: Pearson Education.

Gurbuz, G. dan Aykol, S. 2008, Entrepreneurial Intentions of Young Educated Public in Turkey. Journal of Global Strategic Management, 4(1): 47-56.

Kourilsky, M.L. dan Walstad.W.B. 1998. Entrepreneurship and female youth: knowledge. attitude. gender differences, and educational practices". Journal of Business Venturing. 13 (1),77-88.

Krueger, Norris F. JRa et.al. 2000. Competing Models Of Entrepreneurial Intentions. Journal of Business Venturing Volume 15, Issues 5-6, dalam Sciend Direct, (Online)

(http://www.sciencedirect.com/scie nce/article/pii/S088390269800033

$0)$ diakses tanggal 28 Januari 2013.

Magdalena, L dan B. Soewartoyo. 1992. Ensiklopedi Ekonomi, Bisnis dan 
Manajemen. Jakarta: PT. Cipta Adi Pusaka.

Marbun, B.N. 2003.Kamus Manajemen. Jakarta: Pustaka Sinar Harapan.

Meredith, Geoffrey G. Tanpa Tahun. Kewirausahaan: Teori dan Praktek. Penerjemah Andre Asparsayogi. 2005. Jakarta: PT. Pustaka Binaman Pressindo.

Moekijat. 1993. Evaluasi Pelatihan Dalam Rangka

Peningkatan

Produktivitas. Mandar Maju. Bandung: Penerbit CV Mandar Maju.

Mulyadi, Hari. 2010. Pengaruh Pendidikan Kewirausahaan Terhadap Sikap Kewirausahaan Serta Dampaknya Pada Perilaku Kewirausahaan Mahasiswa, Lembaga Penelitian dan Pengabdian kepada Masyarakat Universitas Pendidikan Indonesia. (online).

(http://penelitian.Ippm.upi.edu/detil/ 1331/pengaruh-pendidikanterhadap-sikap-kewirausahaanserta-implikasinya-pada-perilakukewirausahaan-mahasiswa), diakses 3 November 2012

Mustikawati, Rr. Indah dkk. 2010. Model Pendidikan Kewirausahaa Bagi Pengangguran Perkotaan Penduduk Asli Miskin Kota Yogyakarta. Jurnal Kependidikan, Volume 40, Nomor 1, Mei 2010, hal.119-136, (online), dalam Lembaga Penelitian UNY.(http://journal.uny.ac.id/index. php/jk/article/view/517), diakses 3 November 2012.

Noe et. al. 2003.Human Resource Management, International Edition. New York: The McGraw-hill Companies, Inc.
Pertiwi, Fajriliani Parasamya dkk.2012. Hubungan Kegiatan Training of Trainers dengan Sikap Nasionalisme Pegawai.E-jurnal Mahasiswa Padjadjaran, Vo/. 2., No. 1, (online), dalam Universitas Padjadjaran.

(http://jurnal.unpad.ac.id/ejournal/a rticle/view/2195/pdf_97), diakses 3 November 2012.

Rajasa, Hatta. 2013. Hatta: Kewirausahaan Penting untuk Membangun Bangsa. Dalam Republika. (online) (http://www.republika.co.id/berita/n asional/umum/13/02/09/mhy01dhatta-kewirausahaan-pentinguntuk-membangun-bangsa), diakses tanggal 16 Februari 2013.

Ramayah, T., dan Harun, Z. (2005). Entrepreneurial Intention Among the Student of Universiti Sains Malaysia (USM). International Journal of Management and Entrepreneurship, 1, 8-20.

Riyanto, Astim. 2000. Kapita Selekta Kewirausahaan. Bandung: YAPEMDO.

Sarwoko, Endi. 2001. Kajian Empiris Entrepreneur Intention Mahasiswa.Jurnal Ekonomi Bisnis, Th. 16, No. 2, hal 126-135.dalam Fakultas Ekonomi Universitas Negeri Malang, (Online) (http://fe.um.ac.id/wpcontent/uploads/2009/10/6-EndiSarwoko.pdf), diakses tanggal 28 Januari 2013.

Shapero, A. and Sokol, L. 1982. The social dimensions of entrepreneurship.In C. Kent, D. Sexton and K. Vesper, (Eds.), Encyclopaedia of entrepreneurship, 72-90. 
Soewarno, Noorlailie. Tanpa Tahun. Pengaruh Sikap Terhadap Perilaku Menjadi Mahasiswa Berprestasi: Penelitian Pada Mahasiswa Jurusan Akuntansi Di Fakultas Ekonomi Universitas Airlangga. (online), (http://www.journal.unair.ac.id/deta il jurnal.php?id $=1648 \& \mathrm{med}=27 \& \mathrm{bi}$ $\mathrm{d}=13$ ) diakses tanggal 18 Januari 2013.

Suharti, Lieli dan Hani Sirine. 2011. Faktor-Faktor yang Berpengaruh Terhadap Niat Kewirausahaan (Entrepreneurial Intention). Jurnal Manajemen dan Kewirausahaan, Vol.13, No. 2, 124-134, dalam Pusat Penelitian Petra, (online) (http://puslit2.petra.ac.id/ejournal/i ndex.php/man/article/viewFile/183 29/18174), diakses tanggal 28 Januari 2013.

Walgito, Bimo. 2003. Pengantar Psikologi Umum. Yogyakarta: Andi Offset.

$\mathrm{Wu}, \mathrm{S}$. dan Wu, L. 2008. The Impact of Higher Education on Entrepreneurial Intentions of University Students in China.Journal of Small Business and Enterprise Development, 15(4): 752-774.

Yohnson.2003. Peranan Universitas dalam Memotivasi Sarjana Menjadi Young Entrepreneurs.Jurnal Manajemen dan Kewirausahaan, 5(2): 97-111.

Zimmerer dan Scarborough.2005. Pengantar Kewirausahaan dan Manajemen Kecil. Jakarta: PT. Indeks Gramedia 